\title{
SURVIVAL TIME IN PARAPLEGICS WITH CERTAIN URINARY COMPLICATIONS
}

\author{
By I. Nuse ibeH, F.R.C.S. and R. G. BurR, Ph.D., F.R.S.C. \\ National Spinal Injuries Centre, Stoke Mandeville Hospital, Aylesbury, Buckingham- \\ shire, England.
}

\begin{abstract}
The clinical records of 1025 patients admitted to the National Spinal Injuries Centre between I 944 and I969, (and who later died), were reviewed. Average survival times were obtained following the occurrence of a stone in the urinary tract and following the onset of proteinuria, reduced creatinine clearance and elevated serum creatinine.

The case records of a further 388 patients admitted during 1950, I955 and I 960 but thought to be still living were reviewed for comparison. Their known life span following the onset of the complications studied did not differ from those of the deceased patients in the survey.
\end{abstract}

Key words: Spinal paralysis; Life expectancy; Urinary tract complications.

\section{Introduction}

THE doctor caring for the patient with a spinal cord lesion is frequently called upon to express an opinion as to how much the patient's life is likely to be shortened because he is paralysed.

Nyquist and Bors (1967-68) found that survival in traumatic paraplegics depended on the age of the patient at the time of the accident as well as on the level of the spinal cord lesion and also whether it was complete or incomplete. To these factors Hardy (1976-77) added the delay before admission to hospital after injury. The patient's motivation and family support were mentioned by Carter (1979-80) and to these we would add regular medical examination and prompt re-admission to a spinal unit if complications arise.

One of the common causes of death in late paraplegia is renal failure. We therefore reviewed the records of creatinine clearance, serum creatinine and urinary protein levels and of urinary stone occurrences. By studying these data in patients with known survival time (those who have died), we have tried to obtain information about the relationship between renal disease and survival time.

\section{Material and Methods}

The number of patients admitted to the NSIC during the period 1944 to 1969 was 4688 . Of these 1025 are known to have died and are the main subject of this review (Table I). The dates of onset of spinal cord lesions ranged from the year I9I3 to I969. The delay between onset and admission to the NSIC was from a few hours to 50 years; 50 per cent were admitted within one year and 75 per cent within 4 years of onset of the spinal cord lesion. 
TABLE I

\begin{tabular}{ccc}
\hline & \multicolumn{2}{c}{ Number of Patients } \\
\cline { 2 - 3 } $\begin{array}{c}\text { Year of } \\
\text { Admission }\end{array}$ & Total Admitted & Deceased \\
\hline 1944-9 & 520 & $259(50 \%)$ \\
$1950-4$ & 690 & $243(35 \%)$ \\
$1955-9$ & 890 & $167(19 \%)$ \\
$1960-4$ & 1340 & $202(15 \%)$ \\
$1965-9$ & 1248 & $154(12 \%)$ \\
& 4688 & 1025 \\
\hline
\end{tabular}

So that a comparison could be made between the deceased patients and some who were thought to be still living the years I950, I955 and I960 were selected arbitrarily and the medical records of all admissions were reviewed. From these three years 388 patients were still living and I 28 had died.

Of the 1025 deceased patients, 873 were male and I 52 female. 689 were traumatic, the remainder being non-traumatic in origin. The levels of the traumatic lesions were: cervical 72 complete, I I 4 incomplete; thoracic 3 I 6 complete, 66 incomplete; lumbar 100 complete, 49 incomplete. Of the non-traumatic cases 90 were progressive illnesses such as disseminated sclerosis or malignant disease and 2 I 8 were non-progressive illnesses (transverse myelitis, poliomyelitis, spinal abscess, disc lesion, vascular anomaly, spinal deformity, spina bifida, iatrogenic, etc.).

The results of post mortem examination were available in 320 patients. In 268 (84 per cent) renal failure was a major cause of death. The number of patients known, on the basis of regular radiological examination and/or post mortem findings not to have formed a stone in the urinary tract, was 334. The number of patients who formed stones in the upper urinary tract only was 120 , in the bladder 86 , and in both bladder and upper urinary tract at the same or different times 84 , an association that was highly significant $(P<0.00 \mathrm{I})$. Bilateral renal calculi occurred in 80 patients. In 40 I no calculi were recorded but surveillance was inadequate.

The proportion of patients with renal stones, expressed as a percentage of the total number in each year with adequate surveillance was as follows: I94I, 45 per cent; I95 I, 2 I per cent; I96I, I 5 per cent; I969, I 2 per cent. Table II shows the distribution of times when stones were first observed. For bilateral calculi the time of onset was taken to be the time when a stone was discovered in the second kidney, the other kidney being simultaneously or previously affected.

In 234 patients the date of death was not known, and these, together with a further I 43 patients with spina bifida or progressive illnesses, or who died from associated injuries, pulmonary embolism, accident or suicide were excluded from further study. The number of patients available for survival time study was therefore 648 . No patient received a renal transplant or dialysis.

For the urinary stone data patients were also excluded if the date of first occurrence of the stone was uncertain, or if the stone was present prior to I 944 . 
TABLE II

Interval Between Onset of Spinal Cord Lesion and Detection of Calculus

\begin{tabular}{lcccc}
\hline & $\begin{array}{c}\text { Number Of } \\
\text { Patients }\end{array}$ & $\begin{array}{c}\text { Percentage of Stone-Forming Patients } \\
25 \% \\
\text { occurred } \\
\text { within }\end{array}$ & $\begin{array}{c}50 \% \\
\text { occurred } \\
\text { within }\end{array}$ & $\begin{array}{c}\text { 100\% } \\
\text { occurred } \\
\text { within }\end{array}$ \\
\cline { 2 - 5 } Bladder stones & $9 \mathrm{I}$ & I year & 3 years & 33 years \\
Kidney stones & 89 & $\begin{array}{l}3 \text { years } \\
\text { Bilateral kidney stones }\end{array}$ & $\begin{array}{r}9 \text { years } \\
\text { I I years }\end{array}$ & $\begin{array}{l}33 \text { years } \\
\text { I I years }\end{array}$ \\
\hline
\end{tabular}

Data up to 1953 .

Twenty-four hour urinary protein excretion was usually determined at the same time as creatinine clearance which was introduced as a routine procedure at the NSIC at the beginning of I964. There were 84I urinary protein results obtained from 286 patients and I I 20 creatinine clearance results obtained from 268 .

The attempt was made to determine the dates when urinary protein excretion first exceeded 5 and IO g per 24-hours, when creatinine clearance fell below 50, 25 and $10 \mathrm{ml} / \mathrm{min}$, and when the serum creatinine concentration exceeded I70, 250 and $480 \mathrm{mmol} / \mathrm{l}$ for men and I I 5, I 75 and $340 \mathrm{mmol} / 1$ for women. These values were chosen arbitrarily to represent different degrees of renal impairment, the different values of serum creatinine for men and women being based on the known differences in creatinine production and glomerular filtration rate between the sexes. With severely impaired states of renal function two situations were recognised; firstly, temporary impairment followed by some degree of recovery; secondly, permanent renal failure with no recovery.

Survival time was analysed first in relation to the year when the urinary complication considered was first observed. Maximum survival time for the complication in question was subtracted from I98I, the date of our study. Occurrences of the complication after the year so calculated were excluded from further analysis. The remaining data were analysed in relation to the age of the patient when the complication was observed. The patients were divided into ten-year age groups and the average age and survival time calculated for each one. From these figures average survival time at age $25,35,45,55$ and 65 years were obtained graphically.

\section{Results}

The survival time data for patients with urinary calculi are given in Table III. It is interesting to note that there were no female patients or patients with complete cervical lesions among them.

Table IV gives the survival times for patients with proteinuria of 5 or more grammes per day. The figures for a protein excretion of $\mathrm{I} O \mathrm{~g} /$ day or more were not appreciably different.

Survival times for patients with varying levels of creatinine clearance are given in Table $\mathrm{V}$ and for serum creatinine in Table VI.

No differences in survival time related to level or completeness of cord lesion or the sex of the patient were apparent in any part of this survey. 
TABLE III

Survival Times for Patients with Stones. Interval between Detection and Death.

\begin{tabular}{cccc}
\hline $\begin{array}{c}\text { Age at } \\
\text { Detection }\end{array}$ & \multicolumn{2}{c}{$\begin{array}{c}\text { Mean Survival Time (years) } \\
\text { Bladder Stones }\end{array}$} & \multicolumn{3}{c}{ Kidney Stones } \\
& & Unilat. & Bilat. \\
& $\mathrm{n}=57$ & $\mathrm{n}=86$ & $\mathrm{n}=30$ \\
25 & $\mathrm{I} 8$ & $\mathrm{I} 4$ & $\mathrm{I} 2$ \\
35 & $\mathrm{I} 3$ & $\mathrm{IO}$ & 9.5 \\
45 & 9 & 9 & 7.5 \\
55 & 5 & 5 & 5 \\
65 & 2.5 & 2.5 & 2.5 \\
\hline
\end{tabular}

$\mathrm{n}$ refers to the number of patients

\section{TABLE IV}

Survival Times for Patients Excreting 5 or More Grammes of Urinary Protein per 24 hours. Interval Between First Report of $5 \mathrm{~g}$ Proteinuria and Death. 46 Patients Included

\begin{tabular}{cc}
\hline $\begin{array}{c}\text { Age When } \\
\text { Proteinuria Reported }\end{array}$ & $\begin{array}{c}\text { Mean Survival Time } \\
\text { (years) }\end{array}$ \\
\hline 25 & $3 \cdot 5$ \\
35 & $2 \cdot 8$ \\
45 & $2 \cdot 2$ \\
55 & $\mathrm{I} \cdot 5$ \\
65 & 0.9 \\
\hline
\end{tabular}

\section{TABLE V}

Survival Time in Relation to Creatinine Clearance. Interval Between Time of Observation and Death.

\begin{tabular}{|c|c|c|c|c|c|}
\hline \multirow[t]{2}{*}{$\begin{array}{c}\text { Age of } \\
\text { Observation }\end{array}$} & \multicolumn{5}{|c|}{$\begin{array}{ccc}\text { Mean Survival Time (years) } & \text { When Creatinine Clearance }= \\
50 \mathrm{ml} / \mathrm{min} & 25 \mathrm{ml} / \mathrm{min} & \text { IO } \mathrm{ml} / \mathrm{min} \\
\mathrm{n}=5 \mathrm{I} & \mathrm{n}=48 & \mathrm{n}=28\end{array}$} \\
\hline & & $\begin{array}{c}\text { Temporary } \\
\text { Episode }\end{array}$ & $\begin{array}{c}\text { No } \\
\text { Recovery }\end{array}$ & $\begin{array}{c}\text { Temporary } \\
\text { Episode }\end{array}$ & $\begin{array}{c}\text { No } \\
\text { Recovery }\end{array}$ \\
\hline 25 & 6 & $7 \cdot 2$ & $2 \cdot 3$ & $4 \cdot 2$ & $I \cdot 6$ \\
\hline 35 & 4.9 & 5.9 & $2 \cdot 0$ & 3.5 & 0.9 \\
\hline 45 & $3 \cdot 7$ & $4 \cdot 6$ & $\mathrm{I} \cdot 8$ & 2.9 & 0.5 \\
\hline 55 & $2 \cdot 6$ & $3 \cdot 3$ & I 4 & $2 \cdot 2$ & 0.3 \\
\hline 65 & I 4 & $2 \cdot 0$ & $\mathrm{I} \cdot \mathbf{2}$ & $I \cdot 6$ & 0.2 \\
\hline
\end{tabular}

$\mathrm{n}$ indicates the number of patients included in each group 


\section{TABLE VI}

Survival Time in Relation to Serum Creatinine. Interval Between Time of Observation and Death.

\begin{tabular}{|c|c|c|c|c|c|}
\hline \multirow[t]{2}{*}{$\begin{array}{c}\text { Age of } \\
\text { Observation }\end{array}$} & \multirow[t]{2}{*}{$\begin{array}{c}\text { Mean S } \\
\text { I } 70 \text { mmol/1 } \\
\text { (males) } \\
\text { I I } 5 \mathrm{mmol} / 1 \\
\text { (females) } \\
\text { n }=47\end{array}$} & \multicolumn{2}{|c|}{$\begin{array}{c}250 \mathrm{mmol} / 1 \text { (males) } \\
\text { I } 75 \mathrm{mmol} / 1 \text { (females) } \\
\mathrm{n}=44\end{array}$} & \multicolumn{2}{|c|}{$\begin{array}{c}480 \mathrm{mmol} / 1 \text { (males) } \\
340 \mathrm{mmol} / 1 \text { (females) } \\
\mathrm{n}=37\end{array}$} \\
\hline & & $\begin{array}{c}\text { Temporary } \\
\text { Episode }\end{array}$ & $\begin{array}{c}\text { No } \\
\text { Recovery }\end{array}$ & $\begin{array}{c}\text { Temporary } \\
\text { Episode }\end{array}$ & $\begin{array}{c}\text { No } \\
\text { Recovery }\end{array}$ \\
\hline 25 & $4 \cdot 4$ & 6 & $I \cdot 2$ & 3.5 & $I \cdot 3$ \\
\hline 35 & $3 \cdot 6$ & 5 & $\mathrm{I} \cdot 2$ & $3 \cdot I$ & 0.6 \\
\hline 45 & $2 \cdot 9$ & 4 & $I \cdot 2$ & $2 \cdot 7$ & 0.5 \\
\hline 55 & $2 \cdot 2$ & $3 \cdot I$ & 0.7 & $2 \cdot 3$ & 0.4 \\
\hline 65 & $\mathrm{I} \cdot 4$ & $2 \cdot 2$ & 0.3 & $I \cdot 9$ & 0.3 \\
\hline
\end{tabular}

$\mathrm{n}$ indicates the number of patients included in each group

For the three arbitrarily selected years 1950, 1955 and I960 for which patients who were still living were reviewed, their period of known lifespan following the occurrence of calculi, the onset of proteinuria or renal impairment were within the range of survival times of the deceased patients, and the two sets of data did not differ significantly.

\section{Discussion}

This was a study of deceased patients taken from a population the majority of whom were still living. The results would be erroneous if there existed (in the 'still living' group), patients with calculi, proteinuria or renal dysfunction with survival time following the onset of the complication greater than that of the deceased patients with the same complication. This possibility is excluded, with reasonable certainty, by the results obtained from the small group of 'still living' patients whose case notes were reviewed.

From Table III it appears that (although a bladder calculus does not kill a patient), survival time is shortened, particularly in the higher age groups. In the case of a kidney stone survival times were shorter than for a bladder stone in the younger age groups. Only when kidney stones occurred bilaterally were survival times in the younger age groups reduced still further. We consider that when a patient has a urinary calculus other common complications of paraplegia such as pressure sores, may occur and have an additional effect upon survival.

A urinary protein excretion of five or more grammes daily was related to markedly reduced survival (Table VI) and gave essentially the same survival times as $10 \mathrm{~g}$ proteinuria. It was noticed that lower values of proteinuria (but still over $5 \mathrm{~g}$ per day), sometimes occurred following previous very high values. This may have indicated progression of the 
disease rather than improvement. In many of these cases a diagnosis of amyloidosis was confirmed histologically.

The figures for survival time obtained for patients with impaired creatinine clearance or with elevated serum creatinine concentration (Tables $\mathrm{V}$ and VI) indicate an increasingly poor prognosis with more severely impaired renal function.

Others have reported that the survival of a spinal patient depends on the level and completeness of the cord lesion and on the sex of the patient (Nyquist and Bors, 1967-68). The reason this was not observed in the present study was probably because (in the presence of the urinary complications considered), survival time was already short. In addition, the numbers of patients in the various groups were small.

The survival times reported in this paper are descriptive of the population of patients studied at the NSIC during the period specified. This period included the early years when the modern management of spinal cord injuries was in its infancy and when great advances were being made in management. The results are not, therefore, strictly applicable to other groups of patients treated at this or any other centre.

\section{SUMMARY}

The clinical records of I025 patients admitted to the National Spinal Injuries Centre (NSIC) between I 944 and 1969 and who have subsequently died, were reviewed. Average survival times were obtained following the occurrence of calculi in the bladder or one or both kidneys and following the onset of proteinuria, reduced creatinine clearance and elevated serum creatinine.

The records of a further 388 patients admitted during 1950, I955 and I 960 (but thought to be still living), were reviewed for comparison. Their known life-spans following the onset of the complications studied did not differ from those of the deceased patients in the survey.

For patients with calculi the average survival times were long, varying from I 8 years for a bladder stone at age 25 to 12 years for bilateral renal calculi at the same age. Shorter times were observed for higher ages down to 2.5 years for all categories of calculi at the age of 65 .

For patients with proteinuria exceeding $5 \mathrm{~g}$ per day the survival times varied from 3.5 years at age 25 to 0.9 years at age 65 .

Survival times corresponding to the different creatinine values were in the following ranges: creatinine clearance $50 \mathrm{ml} / \mathrm{min}$, survival time 6 years at age 25 to $\mathrm{I} \cdot 4$ years at age 65 ; creatinine clearance $\mathrm{I} 0 \mathrm{ml} / \mathrm{min}$, survival time $1 \cdot 6$ years at age 25 to 0.2 years at age 65 . Similar figures were obtained for appropriate elevations of serum creatinine.

\section{RÉSUMÉ}

Les régistres cliniques de 1025 malades admis au National Spinal Injuries Centre entre I 944 et 1969 qui mourousent ensuite étaient considérés. Les déais moyens de survivance après l'occurrance d'un calcul de l'urètre, après une attaque d'azoturie, réduction d'excrétion de créatinine et augmentation de crétinine sérique.

Les régistres de 388 autres malades admis pendant I950, I955 et I960 desquels la survivance était présumée étaient considérés pour comparison. La période de survivance constatée après d'attaque des complications étudiées n'était point différente de celle des malades morts considérés. 


\section{ZUSAMMENFASSUNG}

Die Nachforschung der Lebensläufe von 1025, inzwischen verstorbenen Patienten, aufgenommen in den Jahren 1944 bis 1969 im National Spinal Injuries Centre, ergab eine durchnittliche Überlebenszeit. Es traten Komplikationen auf, wobei wir uns mit Komplikationen im Harntrakt durch einen Stein, die zur Folge einen Anfall von Proteinurie, zurückzufuhren auf eine Creatininfreilegung und erhöhtem Creatininserum hatte, beschäftigt haben. Weitere Nachforschungen von Lebensverläufen von 388 , noch lebenden Patienten, aufgenommen während den Jahren 1950, I955 und 1960 ergab, zurücklickend, keine wesentlichen Unterschiede von Komplikationsangriffen zu denen im Vergleich der oben genanten Verläufe.

Acknowledgment: We thank Mr G. J. Fellows for his criticism of the manuscript.

\section{REFERENCES}

Carter, R. E. (1979-80). Experiences with high tetraplegics. Paraplegia, 17, I40-146. HARDY, A. G. (1976-77). Survival periods in traumatic paraplegia. Paraplegia, 14, 4I-46. NYQUIST, R. H. \& BoRS, E. (1967-68). Mortality and survival in traumatic myelopathy during nineteen years from I946 to 1965. Paraplegia, 5, 22-49. 